\title{
Impairment of Mitochondrial Function of Rat Hepatocytes by High Fat Diet and Oxidative Stress
}

\author{
T. GARNOL ${ }^{1}$, R. ENDLICHER ${ }^{1,2}$, O. KUČERA ${ }^{1}$, Z. DRAHOTA $^{1,3}$, Z. ČERVINKOVÁ $^{1}$ \\ ${ }^{1}$ Department of Physiology, Charles University in Prague, Faculty of Medicine in Hradec Králové, \\ Czech Republic, ${ }^{2}$ Department of Anatomy, Charles University in Prague, Faculty of Medicine in \\ Hradec Králové, Czech Republic, ${ }^{3}$ Institute of Physiology Academy of Sciences of the Czech \\ Republic, Prague, Czech Republic
}

Received August 20, 2013

Accepted October 22, 2013

On-line January 8, 2014

\begin{abstract}
Summary
Fatty liver disease associated with obesity is an important medical problem and the mechanisms for lipid accumulation in hepatocytes are not fully elucidated yet. Recent findings indicate that mitochondria play an important role in this process. Our data on hepatocytes in which mitochondria are in contact with other cytosolic structures important for their function, extend observations obtained on isolated mitochondria and confirm inhibition of Complex I activity in hepatocytes isolated from rats fed by high fat diet (HFD) compared with controls fed by standard diet (STD). Furthermore we have found that HFDhepatocytes are more sensitive to the peroxidative stress because under these conditions also Complex II activity is disturbed. Therefore in HFD animals decrease of Complex I activity cannot be compensated by Complex II substrates as in STD hepatocytes. Our data thus indicates that combination of HFD and peroxidative stress potentiates HFD damaging effect of mitochondria because both branches of the respiratory chain (NADH- and flavoprotein-dependent) are disturbed.
\end{abstract}

\section{Key words}

Hepatocytes • High/fat diet • Mitochondrial activities • ROS

\section{Corresponding author}

Z. Červinková, Department of Physiology, Charles University in Prague, Faculty of Medicine in Hradec Králové, Šimkova 870, 50038 Hradec Králové, Czech Republic. E-mail: wolff@lfhk.cuni.cz
Non-alcoholic fatty liver disease (NAFLD) is recognized as the most common chronic liver disease in the Western world and its primary form is considered to be the hepatic manifestation of metabolic syndrome. Although the mechanisms responsible for increased accumulation of lipids in the liver are not yet fully elucidated, decreased capacity to oxidise fatty acids, increased transport of fatty acids to the liver and increased hepatic fatty acid synthesis seem to be important factors in the pathogenesis of NAFLD (Begriche et al. 2006, Wei et al. 2008). There are evidences that abnormalities in mitochondrial morphology and functions are involved in initiation and progression of NAFLD (Vendemiale et al. 2001, Mantena et al. 2009, Begriche et al. 2013). Higher formation of reactive oxygen and/or nitrogen species (ROS/RNS), decreased hepatic ATP production and induction of proinflammatory cytokines lead to steatohepatitis (Serviddio et al. 2008). Steatosis is still poorly understood since diverse effects have been reported, depending on the different model used to induce NAFLD.

Recent findings indicate that cell energy metabolism is modified by the lipotoxic effect of nutritional lipids. Vial et al. (2011) have shown that isolated mitochondria from rats nourished by a high-fat diet have decreased rate of mitochondrial oxidation and increased rate of mitochondrial ROS production. We decided to extend these observations and to obtain additional data, thereby supporting the hypothesis that

PHYSIOLOGICAL RESEARCH • ISSN 0862-8408 (print) • ISSN 1802-9973 (online)

(c) 2014 Institute of Physiology v.v.i., Academy of Sciences of the Czech Republic, Prague, Czech Republic

Fax +420 241062 164, e-mail: physres@biomed.cas.cz,www.biomed.cas.cz/physiolres 
increased ROS production participates on mitochondrial dysfunction induced by high-fat diet. We used isolated hepatocytes where mitochondria are in contact with other intracellular components that are important for their optimal functional activity (Kondrashova et al. 2001, 2009).

We have studied the effect of high-fat diet on the activity of mitochondrial respiratory chain function using male albino Wistar rats (Biotest, Czech Republic) housed under standard conditions as described before (Červinková et al. 2009). Rats of the first, control group were fed ad libitum by a standard pelleted diet (ST-1, Velaz, Prague, CR; $10 \%$ energy fat, $30 \%$ energy proteins, $60 \%$ energy saccharides) for 6 weeks (STD). Rats of the other, experimental group were fed by a highfat diet (HFD; $71 \%$ energy fat, $18 \%$ energy proteins, $11 \%$ energy saccharides) according to Lieber et al. (2004). Our previous study performed under equal experimental conditions showed that male Wistar albino rats fed by HFD developed simple steatosis without signs of progression to non-alcoholic steatohepatitis (Kučera et al. 2011). All animals received care according to the guidelines set by the Institutional Animal Use and Care Committee of the Charles University, Prague, Czech Republic.

Hepatocytes were isolated by two-step collagenase perfusion (Berry et al. 1991). The viability of isolated hepatocytes was more than $90 \%$ as confirmed by trypan blue exclusion test. Respiration of isolated, digitonin-permeabilized hepatocytes was measured by High-resolution Oxygraph OROBOROS-K2 (Austria) as described before (Drahota et al. 2005, Červinková et al. 2009, Endlicher et al. 2009).

Digitonin-permeabilized hepatocytes were incubated at $30^{\circ} \mathrm{C}$ in $2 \mathrm{ml}$ of a $\mathrm{K}$-medium containing $80 \mathrm{mM} \mathrm{KCl}, 10 \mathrm{mM}$ Tris $\mathrm{HCl}, 4 \mathrm{mM} \mathrm{K}$-phosphate, $3 \mathrm{mM}$ $\mathrm{MgCl}_{2}, 1 \mathrm{mM}$ EDTA, and $\mathrm{pH}$ 7.4. For evaluation of oxygen uptake OROBOROS DatLab-4 software was used. For the evaluation of toxic effects of tert-butyl hydroperoxide (BHP) on function of mitochondrial enzyme complexes hepatocytes were incubated with $0.25 \mathrm{mM}$ BHP for $5 \mathrm{~min}$ before addition of respiratory substrates. $10 \mathrm{mM}$ glutamate $+2.5 \mathrm{mM}$ malate and $1.5 \mathrm{mM}$ ADP were used for evaluation of the Complex I function and succinate was used as substrate for Complex II.

General scheme of oxygraphic measurements depicts Figure 1. Mean values comparing STD and HFD groups with and without BHP are summarized in Table 1. After passing D'Agostino's normality test, significant differences were evaluated using unpaired Student's t-test (GraphPad Prism4.03, GraphPad Software, CA) at the selected level of significance of $\mathrm{p}<0.05$.

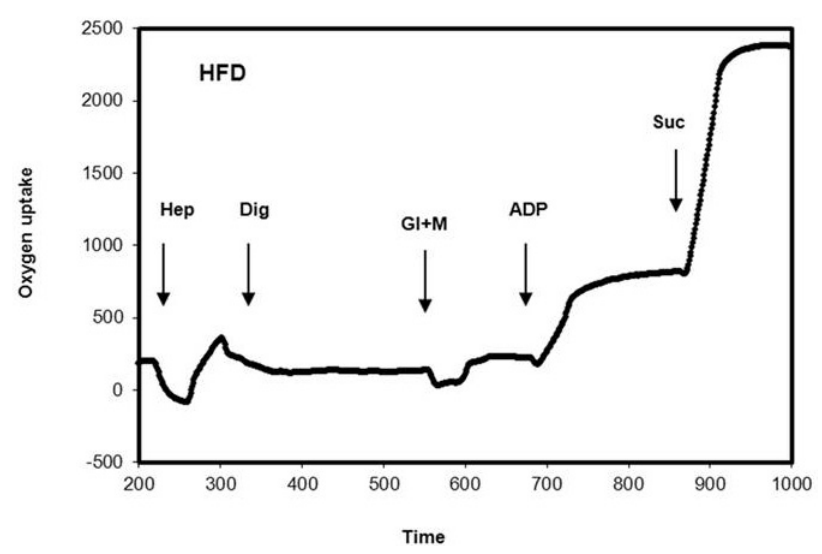

Fig. 1. Respiration of rat liver hepatocytes isolated from animals fed by the high-fat diet (HFD). To the $2 \mathrm{ml}$ of K-medium $\left(30^{\circ} \mathrm{C}\right.$ ) hepatocytes (Hep) $(250000 / \mathrm{ml})$ were added followed by $20 \mu \mathrm{g} / \mathrm{ml}$ Digitonin (Dig), $10 \mathrm{mM}$ Glutamate $+2.5 \mathrm{mM}$ Malate $(\mathrm{Gl}+\mathrm{M}), \quad 1.5 \mathrm{mM}$ ADP and $10 \mathrm{mM}$ succinate. When BHP $(0.25 \mathrm{mM})$ was tested it was added after Dig and $\mathrm{Gl}+\mathrm{M}$ were added after 5 min. Oxygen uptake was expressed as pmole oxygen/s/million cells, time in seconds.

From the data presented in the Table 1 it is evident that Complex I activity was reduced in hepatocytes isolated from HFD animals, which is in agreement with the data obtained using isolated liver mitochondria by Vial et al. (2011) and Mantena et al. (2009). Data in Figure 1 show that Complex I activity cannot fully saturate respiratory chain capacity because after addition of succinate as Complex II substrate, respiratory rate of hepatocytes from all experimental groups tested is further increased. In hepatocytes isolated from HFD animals succinate addition fully compensated decreased Complex I activity (Table 1). This demonstrates that Complex II activity is not affected under our experimental conditions in contrary to findings observed on isolated rat mitochondria by Vial et al. (2011) and isolated mice mitochondria by Mantena et al. (2009). This difference could be explained by lower ROS production during a shorter period of feeding animals with the high fat diet in our experiments which induces simple steatosis without inflammatory response. The other reason could be different models (mitochondria vs hepatocytes) used. 
Table 1. Respiration of digitonin-permeabilized hepatocytes isolated from rats fed by standard (STD) and high-fat diet (HFD).

\begin{tabular}{lcc}
\hline & Gl+Mal+ADP & Gl+Mal+ADP+Suc \\
\cline { 2 - 3 } & \multicolumn{2}{c}{$(\mathbf{p m o l}$ oxygen/s/milion cells) } \\
\hline$S T D(n=15)$ & $1073.4 \pm 41.24$ & $1764.1 \pm 70.03$ \\
$S T D+B H P(n=11)$ & $812.0 \pm 57.14$ & $1527.8 \pm 86.44$ \\
$H F D(n=12)$ & $954.3 \pm 44.98$ & $1848.5 \pm 146.63$ \\
$H F D+B H P(n=10)$ & $575.1 \pm 39.84$ & $1406.7 \pm 105.72$ \\
$\% H F D / S T D$ & $-11(\mathrm{p}=0.031)$ & $5(\mathrm{n} . \mathrm{s})$. \\
$\% S T D+B H P / S T D$ & $-24(\mathrm{p}=0.0007)$ & $-13(\mathrm{p}=0.00361)$ \\
$\% H F D+B H P / H F D$ & $-40(\mathrm{p}=0.0199)$ & $-34(\mathrm{p}=0.014)$ \\
\hline
\end{tabular}

The results are expressed as the means \pm standard errors of the mean (SEM). Glutamate and malate (GI+Mal) and ADP (Complex I activity) and after GI+Mal, ADP and succinate (Suc; Complex I + Complex II activities) were tested under conditions described in Figure 1. In both groups, changes of respiratory rates induced by BHP were also measured under conditions described in Figure 1.

We have therefore tested whether the inhibitory effect of HFD on Complex I+II activity could be increased by combination of the high-fat diet with the peroxidative stress. In agreement with our previous findings (Drahota et al. 2005), we have confirmed that inhibition of Complex I by BHP in animals fed by the STD can be fully compensated by succinate (Table 1). However, the significant decrease induced by BHP and HFD was not compensated (Table 1, HFD +/- BHP). Therefore under these experimental conditions when both deleterious factors namely HFD and oxidative stress are combined also Complex II activity was depressed.

The inhibitory effect of high fat diet is quite similar to our previous observations that have shown that Complex I in comparison to Complex II, is more sensitive to the inhibitory effect of the oxidative stress (Endlicher et al. 2009) and to biguanides inhibitory action (Páleníčková et al. 2011). In these experiments, also the inhibition of Complex I was as well fully compensated by the Complex II function. However at higher concentrations of toxic agents used, inhibition of Complex II was also observed (Drahota et al. 2014).
We may thus conclude that changes of the cell energetics induced by the high fat diet are related to the Complex I disturbances and under normal conditions may be compensated by utilization of nutritional flavoproteindependent substrates, that can bypass Complex I. However when two factors, e.g. high fat diet and oxidative stress are combined the inhibition is more pronounced because under these conditions both branches of the respiratory chain (NADH- and flavoproteindependent) are disturbed.

\section{Conflict of Interest}

There is no conflict of interest.

\section{Acknowledgements}

This work was supported by the programme PRVOUK P37/02 and by the grant LL1204 (within the ERC CZ program) from Ministry of Education, Youth and Sport of the Czech Republic. The authors are grateful to Mr. Remus Anthraper, M.D., for linguistic revision of the manuscript.

\section{References}

BEGRICHE K, IGOUDJIL A, PESSAYRE D, FROMENTY B: Mitochondrial dysfunction in NASH: Causes, consequences and possible means to prevent it. Mitochondrion 6: 1-28, 2006.

BEGRICHE K, MASSART J, ROBIN MA, BONNET F, FROMENTY B: Mitochondrial adaptations and dysfunctions in nonalcoholic fatty liver disease. Hepatology 58: 1497-1507, 2013.

BERRY MN, EDWARDS AM, BARRITT GJ: High-yield preparation of isolated hepatocytes from rat liver. In: Isolated Hepatocytes Preparation, Properties and Application. BURDON RH, VAN KNIPPENBERG PH (eds), Elsevier, New York, 1991, pp 15-81. 
ČERVINKOVÁ Z, KŘIVÁKOVÁ P, LÁBAJOVÁ A, ROUŠAR T, LOTKOVÁ H, KUČERA O, ENDLICHER R, ČERVINKA M, DRAHOTA Z: Mechanisms participating in oxidative damage of isolated rat hepatocytes. Arch Toxicol 83: 367-372, 2009.

DRAHOTA Z, KŘIVÁKOVÁ P, ČERVINKOVÁ Z, KMONÍČKOVÁ E, LOTKOVÁ H, KUČERA O, HOUŠTĚK J: Tert-butyl hydroperoxide selectively inhibits mitochondrial respiratory enzymes in isolated rat hepatocytes. Physiol Res 54: 67-72, 2005.

DRAHOTA Z, PÁLENÍČKOVÁ E, ENDLICHER R, MILEROVÁ M, BREJCHOVÁ J, VOŠAHLÍKOVÁ M, SVOBODA P, KAZDOVÁ L, KALOUS M, ČERVINKOVÁ Z, CAHOVÁ M: Biguanides inhibit Complex I, II, IV of rat liver mitochondria and modify their functional properties. Physiol Res 63: 1-11, 2014.

ENDLICHER R, KŘIVÁKOVÁ P, RAUCHOVÁ H, NUSKOVÁ H, ČERVINKOVÁ Z: Peroxidative damage of mitochondrial respiration is substrate-dependent. Physiol Res 58: 685-692, 2009.

KONDRASHOVA MN, FEDOTCHEVA NI, SAAKYAN IR, SIROTA TV, LYAMZAJEV KG, KULIKOVA MV, TEMNOV AV: Preservation of native properties of mitochondria in rat liver homogenate. Mitochondrion 1: 249-267, 2001.

KONDRASHOVA M, ZAKHARENKO M, KHUNDERYAKOVA N: Preservation of the in vitro state of the mitochondrial network for ex vivo physiological study of mitochondria. Internat $J$ Biochem Cell Biol 41: 2036-2050, 2009.

KUČERA O, GARNOL T, LOTKOVÁ H, STAŇKOVÁ P, MAZUROVÁ Y, HROCH M, BOLEHOVSKÁ R, ROUŠAR T, ČERVINKOVÁ Z: The effect of rat strain, diet composition and feeding period on the development of a nutritional model of non-alcoholic fatty liver disease in rats. Physiol Res 60: 317-328, 2011.

LIEBER CS, LEO MA, MAK KM, XU Y, CAO Q, REN C, PONOMARENKO A, DECARLI LM: Model of nonalcoholic steatohepatitis. Am J Clin Nutr 79: 502-509, 2004.

MANTENA SK, VAUGHN DP, ANDRINGA KK, ECCLESTON HB, KING AL, ABRAMS GA, DOELLER JE, KRAUS DW, DARLEY-USMAR VM, BAILEY SM: High fat diet induces dysregulation of hepatic oxygen gradients and mitochondrial function in vivo. Biochem J 417: 183-193, 2009.

PÁLENÍČKOVÁ E, CAHOVÁ M, DRAHOTA Z, KAZDOVÁ L, KALOUS M: Inhibitory effect of metformin on oxidation of NADH-dependent substrates in rat liver homogenate. Physiol Res 60: 835-839, 2011.

SERVIDDIO G, SASTRE J, BELLANTI F, VINA J, VENDEMIALE G, ALTOMARE E: Mitochondrial involvement in non-alcoholic steatohepatitis. Mol Aspects Med 29: 22-35, 2008.

VENDEMIALE G, GRATTAGLIANO I, CARACENI P, CARACCIO G, DOMENICALI M, DALL'AGATA M, TREVISANI F, GUERRIERI F, BERNARDI M, ALTOMARE E: Mitochondrial oxidative injury and energy metabolism alteration in rat fatty liver: effect of the nutritional status. Hepatology 33: 808-815, 2001.

VIAL G, DUBOUCHAUD H, COUTURIER K, COTTET-ROUSSELLE C, TELEAUX N, ATHIAS A, GALINIER A, CASTEILLA L, LEVERVE XM: Effects of a high-fat diet on energy metabolism and ROS production in rat liver. J Hepatol 54: 348-356, 2011.

WEI Y, RECTOR RS, THYFAULT JP, IBDAH JA: Nonalcoholic fatty liver disease and mitochondrial dysfunction. World J Gastroenterol 14: 193-199, 2008. 